\title{
Badacz wobec doświadczeń dorosłych w kontekście biograficznej perspektywy badawczej
}

\begin{abstract}
Abstrakt
Przyglądając się współczesnym praktykom badawczym realizowanym w obszarze nauk społecznych, można dostrzec wyraźne zainteresowanie biografią. Obserwacja losów jednostek, (roz)poznawanie mikroświatów społecznych z perspektywy indywidualnych biografii, a także analiza i poszukiwanie znaczeń indywidualnych doświadczeń życiowych człowieka cieszy się dużym zainteresowaniem, ale również zaufaniem wśród badaczy. Można także dostrzec, iż badacze z coraz większą uwagą i rozwagą zastanawiają się nad prawomocnością i poprawnością metodologiczną realizowanych przez siebie projektów, co jest szczególnie ważne w sytuacji konieczności problematyzowania i dookreślania tożsamości metodologicznej podejścia biograficznego.

Niniejszy tekst jest głosem w dyskusji na temat rodzajów tzw. badań biograficznych realizowanych $w$ obszarze andragogiki oraz ich istoty. Punktem wyjścia jest postrzeganie badań z wykorzystaniem biografii przez pryzmat biograficznej perspektywy badawczej, która przyjmować może przynajmniej trzy formy. Są nimi: podejście biograficzne, podejście auto/biograficzne i podejście autobiograficzne. Osią rozważań staje się refleksja związana z dookreśleniem poszczególnych podejść w odniesieniu do konkretnych projektów badawczych, z uwzględnieniem specyficznej roli/ról, jaką pełni w nich badacz. W tekście zostaje również zasygnalizowany wątek odnoszący się do rozumienia procesu badawczego z perspektywy procesu uczenia się. Źródłem podejmowanych rozważań są indywidualne doświadczenia badaczek, płynące z realizacji projektu, w którym wykorzystano podejście auto/biograficzne.
\end{abstract}

Słowa kluczowe: biografia, badania biograficzne, badania autobiograficzne, badania auto/biograficzne, badania andragogiczne.

\footnotetext{
* Uniwersytet Wrocławski, Wydział Nauk Historycznych i Pedagogicznych, Instytut Pedagogiki, Zakład Edukacji Dorosłych i Studiów Kulturowych.
} 


\title{
Researcher and Experiences of Adults in the Biographical Research Perspective
}

\begin{abstract}
Looking at today's research practices applied in the area of social sciences one can notice a clear interest in biography. Observation of the lives of individuals, (re)cognition of social micro worlds from the perspective of individual biographies and analysis of and searching for meanings of individual life experiences are the subjects of great interest as well as confidence among researchers. It is also noticeable that researchers, with even greater attention and concern, contemplate the methodological legitimacy and correctness of the projects they carry out. This is especially important when there is a necessity to problematize and further specify the methodological identity of the biographical approach.

This text is a voice in the discussion about the types and nature of the so-called biographical research conducted in the area of andragogy. Its starting point is viewing the research that uses biography through the lens of the biographical research perspective, which may adopt at least three forms: biographical approach, auto/ biographical approach and autobiographical approach. The considerations revolve around reflections about specifying the individual approaches in relation to certain research projects taking into account the specific role/roles played in them by the researcher-andragogue. The text also addresses the topic of understanding the research process from the perspective of the learning process. The reflections are based on the individual experiences of the researchers acquired during the project in which the auto/biographical approach was applied.
\end{abstract}

Keywords: biography, biographical research, autobiographical research, auto/ biographical research, andragogical research.

Badania mikroświatów ludzi dorosłych skorelowane są z wieloma praktykami metodologicznymi, które z kolei zakorzenione są w różnych nurtach i teoriach andragogicznych. Biorąc pod uwagę już choćby tylko współczesne odmiany teorii andragogicznych, da się zaobserwować, iż dowartościowują one dorosłych jako autonomicznych i kreatywnych uczących się. W efekcie, „bycie badaczem” często wymyka się utartym schematom postępowania badawczego, angażując niestandardowe techniki gromadzenia danych oraz metody ich interpretacji, co sprzyja świadomemu, refleksyjnemu i twórczemu (roz)poznawaniu świata dorosłych. W tym kontekście, szczególnie ważne wydaje się umożliwienie badaczom włączania własnych życiowych doświadczeń zarówno w szeroko pojęte procesy badawcze, jak i edukacyjne. Sytuowany w takiej perspektywie proces badawczy staje się nie tylko specyficzną przestrzenią (roz)poznawania wybranych fragmentów rzeczywistości społecznej, ale też swoistym obszarem uczenia się samego badacza.

Badania dopuszczające umieszczanie doświadczeń i historii życia zarówno badanych, jak i badaczy w centrum zainteresowań badawczych wpisują się w tzw. 
nurt biograficzności, przybierający trzy podstawowe formy; są nimi: podejście biograficzne, podejście autobiograficzne i podejście auto/biograficzne. Pośród wymienionych, wyjątkowo ciekawym poznawczo wydaje się być podejście auto/biograficzne, w którym dochodzi do zintegrowania sfery badawczej ze sferą edukacyjną; mówiąc inaczej, w toku auto/biograficznego procesu poznania osoby biorące udział w badaniach często przyjmują pozycję uczących się podmiotów.

W niniejszym tekście podejmiemy próbę określenia specyfiki podejść badawczych z wykorzystaniem biografii, skupiając się przede wszystkim na możliwościach zastosowania podejścia auto/biograficznego $\mathrm{w}$ badaniach skoncentrowanych na doświadczeniach dorosłych; przyjrzymy się rolom badacza w tego typu praktykach, a także zasygnalizujemy kwestię procesu jego uczenia się. Główne pytania, na które będziemy poszukiwały odpowiedzi w naszym tekście, brzmią: „Czym charakteryzują się poszczególne podejścia badawcze ukierunkowane na badanie biografii?” oraz „Jakiego rodzaju zmiany niesie ze sobą uczestnictwo w tego rodzaju badaniach dla badacza?".

\section{Podejścia badawcze z wykorzystaniem biografii - próba metodologicznego ujęcia}

Badania z wykorzystaniem biografii, przez wzgląd na ich w dużej mierze interdyscyplinarny charakter, z jednej strony dają badaczom sporą autonomię w konstruowaniu nowych projektów, z drugiej strony cechująca je interdyscyplinarność przyczynia się do pomnażania trudności wynikających z konieczności radzenia sobie z nierzadko mało kompatybilną warstwą teoretyczno-metodologiczną, jaką badacz ma do dyspozycji. Pisała o tym m.in. Elżbieta Dubas, stwierdzając, iż tego rodzaju poszukiwania „nastręczają wielu trudności i rodzą wiele pytań. Wciąż wymagają od badaczy uczenia się (w) tej niedookreślonej rzeczywistości badawczej" (Dubas 2011: 6).

Fakt, że podejmowanie badań biograficznych każdorazowo jest sporym wyzwaniem dostrzega także Alicja Jurgiel, która zauważa, iż „rozumienie biografii przez autorów badań jest pochodną sposobu pojmowania charakteru badanego zjawiska oraz świadomości rodzaju wiedzy, do którego ma prowadzić proces badania" (Jurgiel-Aleksander 2013: 62). Jednocześnie ta sama autorka wskazuje na trzy sposoby traktowania biografii przez andragogów: 1 - biografia jako świadectwo zdarzeń historycznych, 2 - biografia jako lustro doświadczeń kulturowych w rozumieniu antropologicznym, 3 - spojrzenie na biografię przez pryzmat mechanizmu jej konstruowania (rozumienie narracji jako rezultatu zgromadzonych faktów z historii życia, ale również jako strukturę, w której przebiega proces rozumienia) (tamże).

Różnice $\mathrm{w}$ biograficznych podejściach badawczych dotyczą także sposobów odnoszenia się do podstawowych terminów - biografii i autobiografii. Dla przykła- 
du, czynienie rozróżnienia między biografiqa a autobiografią tłumaczone jest m.in. jako wynikające z modelu uprawiania nauki (Skibińska 2006: 330). Zgodnie z tym stanowiskiem, biografia wpisywana jest w paradygmat pozytywistyczny, z kolei autobiografia w nurt myślenia antypozytywistycznego.

W kanonie tradycji pozytywistycznej chętniej odnosimy się do biografii traktowanej jako sprawozdanie z życia, zawierające obiektywny opis faktów, wydarzeń i osób. Antypozytywiści natomiast skłonni są gloryfikować autobiografię, jako że kojarzona jest ona z bytem subiektywnym. Wedle takiego pojmowania autobiografii jest ona wytworem działalności podmiotu, zależy od świadomości jednostki, ma charakter ciągłego procesu, jest kontekstualna (osadza się w czasie i przestrzeni, w tym, co społeczne i kulturowe), wreszcie - istnieje dzięki przekazowi językowemu. Przyjmuje się, że jednostka posługująca się formą autobiograficzną jest wyrazicielem życia zapośredniczonego przez symbole, znaczenia i wartości (Giza-Poleszczuk 1990: 96-99; Skibińska 2006: 330-332; zob. Golonka-Legut 2015: 107).

Takie i im podobne problemy rodzą wątpliwości, czy czyniąc z biografii przedmiot badań, powinniśmy mówić o metodzie, podejściu, perspektywie czy może paradygmacie badawczym? Bliskie nam jest w tej kwestii stanowisko zaproponowane przez Danutę Urbaniak-Zając postulującą przyjęcie pedagogicznej perspektywy biograficznej, w obrębie której biografię traktuje się jako historię życia człowieka, „będąc[ą] jednocześnie historią jego uczenia się, czy też kształtowania" (Urbaniak-Zając 2011: 20). W związku z tym doceniona zostaje - po pierwsze - specyfika przedmiotu naukowej pedagogiki, w tym andragogiki jako jej subdyscypliny, po drugie, uznanie zyskuje różnorodność i otwartość biograficznej perspektywy badawczej, ponieważ „pod nazwą biografia kryją się odmienne konstrukty teoretyczne" (tamże: 17; wyróżnienia w oryginale).

Dostrzegając zarysowaną powyżej teoretyczną i metodologiczną różnorodność, podjęłyśmy próbę systematyzacji praktyk badawczych z wykorzystaniem biografii, które to rozwiązania, jak już sygnalizowałyśmy, mogą przyjmować trzy główne formy: biograficzną, auto/biograficzną i autobiograficzną. W przypadku podejścia biograficznego przedmiotem badań staje się biografia ludzi tworzona w określonych warunkach społeczno-kulturowych i historycznych. Jest ona interesująca przez wzgląd na dane cechy i ich zmienną konfigurację; motywy poznania owych układów cech wyartykułowane zostają w danej problematyce badawczej. Badacz, korzystający z podejścia biograficznego, skoncentrowany jest na indywidualnych aktorach świata społecznego i tym, co dzięki ich poznaniu może on powiedzieć o światach, w których ci aktorzy żyją. W celu opisania indywidualnych doświadczeń sięga się tu do teorii zakorzenionych m.in. w paradygmatach konstruktywistycznym i humanistycznym. Umożliwiają one poleganie na rozumieniu i interpretacji analizowanej biografii, $\mathrm{z}$ uwzględnieniem własnej intuicji i wiedzy badacza. Podejście to rozpowszechnione zostało m.in. dzięki klasycznemu dziełu Williama Isaaca Thomasa i Floriana Znanieckiego pt. Chłop polski $w$ Europie i Ameryce (Thomas, Znaniecki 1918-1921, za: Bron 2009: 37). Dobrym przykładem 
współczesnych badań, wykorzystujących podejście biograficzne jest studium Ewy Skibińskiej pt. Mikroświaty kobiet. Relacje autobiograficzne (2006). Autorka przedmiotem zainteresowań badawczych uczyniła autobiografie kobiet - słuchaczek Uniwersytetu Trzeciego Wieku oraz mieszkanek Domu Pomocy Społecznej „Kombatant". Celem badań było poznanie mikroświatów, w jakich funkcjonowały narratorki, $\mathrm{z}$ naciskiem na oddanie niepowtarzalności przynależnych im przestrzeni społecznych. Zastosowaną metodą badań był autobiograficzny wywiad narracyjny (2006: 330, 335). Warto zaznaczyć, iż Skibińska źródło swoich badań określa jako „autobiografie” kobiet, uwypuklając ich indywidualny charakter i pochodzenie.

Na nieco inne rozwiązanie zdecydowała się Emilia Mazurek, która powołując się na Liz Stanley odróżnia biografię od autobiografii. W publikacji pt. Biografie edukacyjne kobiet dotkniętych rakiem piersi jej autorka podkreśla, że człowiek konstruuje własną autobiografię i jednocześnie tworzy biografie innych ludzi (Stanley 2008, za: Mazurek 2013: 89). Mazurek skupia się na biografiach edukacyjnych kobiet dotkniętych rakiem piersi, przedmiotem analizy czyniąc narracje autobiograficzne prezentujące subiektywny obraz świata (tamże). Z kolei Joanna Golonka-Legut (2013), badając „potencjał edukacyjny osób starszych z perspektywy czasu", w nawiązaniu do koncepcji biograficzności w ujęciu Petera Alheita (2011: 7-21) wskazuje na biograficzną perspektywę jako drogę postępowania badawczego. Autorka przyjmuje wyróżnione wcześniej stanowisko Danuty Urbaniak-Zając (2011), optującej za - podkreślmy - rezygnacją z określenia „metoda biograficzna” na rzecz terminu „biograficzna perspektywa badawcza”. Zastosowaną przez Golonkę-Legut metodą był wywiad jakościowy; technikami badawczymi biograficzny wywiad narracyjny, wywiad biograficzny na podstawie zdjęć i dokumentów osobistych narratorów, wywiad biograficzny w oparciu o mapy doświadczeń osobistych. W badaniach tych punktem wyjścia były narracje autobiograficzne osób badanych. W rezultacie, przedmiotem badań omawianego projektu stał się potencjał edukacyjny doświadczenia życiowego osób starszych widziany z perspektywy czasu, na przedmiot interpretacji złożyły się natomiast wypowiedzi autobiograficzne dotyczące potencjału edukacyjnego doświadczenia życiowego, mające postać narracji, opisu oraz argumentacji (zob. Helling 1990: 30).

Co ważne, wydaje się, iż wspomniani autorzy dostrzegają społeczno-kulturowe i historyczne uwarunkowania analizowanych biografii, niemniej jednak, wchodząc $\mathrm{w}$ relacje z badanymi-narratorami, nie poszukują związków ich doświadczeń z własnym zapleczem biograficznym. Taka sytuacja może być konsekwencją np. braku osobistych doświadczeń badacza, ściśle łączących się z podejmowaną tematyką badawczą. Decyzja o wykluczeniu siebie z, nazwijmy to, „pełnej” partycypacji w praktykach badawczych może wynikać m.in. z przekonania o rozdzielności i nieprzystawalności jego mikroświata względem życia osób badanych. Pomimo osadzenia badań w paradygmacie humanistycznym, subiektywizm badacza odnosi się w takiej sytuacji do wysiłków rozumienia historii życia, które są historiami innych ludzi, nie zaś historiami jego samego. 
W kontekście prowadzonych rozważań, istotną wydaje się być refleksja nad podmiotowością badanych i badacza w eksploracjach naukowych wtedy, gdy podmiotowość stanowi jeden z warunków niezbędnych do realizacji badań. Wspólne uczestnictwo $\mathrm{w}$ badanych światach społecznych wiąże się z przyjęciem otwartej postawy wobec własnej, indywidualnej obecności i doświadczania zjawisk będących przedmiotem badania. W tym sensie, pewnym dopełnieniem owego wzajemnego uczestnictwa w światach społecznych może być refleksja sięgająca przyczyn podjętych działań badawczych. Badacz, po głębokim namyśle, może dotrzeć do takich elementów w osobistych doświadczeniach, które stanowić mogą nie tylko praprzyczynę podjętych wysiłków poznawczych, lecz zarazem tworzą one pewnego rodzaju zapośredniczoną płaszczyznę podzielanego bycia w świecie. Opisywane momenty mogą przyjąć postać epifanii, tzw. momentów kryzysowych, przełomowych i zdarzeń zwrotnych i w tym sensie stanowiących istotne części historii życia (Kafar 2011: 44). Tak rozumiane epifanie, uwspólnione z badanymi lub indywidualne, mogą wywierać wpływ na postawy poznawcze badacza. Zdarza się, iż owe doświadczenia są tak intensywne, iż badacz postanawia przyjrzeć się im z poziomu poznania naukowego. W tym celu może wykorzystać on podejście autobiograficzne, w którym własne doświadczenie życiowe czyni przedmiotem naukowej autoanalizy (zob. Pryszmont-Ciesielska 2009). Praktyki badawcze, które dowartościowują „ja” badacza, odnajdują swe uzasadnienie w paradygmacie postmodernistycznym (por. Malewski 1998). Robin Usher, odsłaniając autobiograficzny wymiar tych praktyk, podkreśla, iż indywidualne trajektorie badaczy są obecne w prowadzonych przez nich badaniach i realnie kształtują otrzymane efekty (Usher 1996, za: Malewski 1998). Z tego powodu badacz decyduje się opowiedzieć o sobie i przybliżyć swoje doświadczenie życiowe. Wydaje się, iż w takim wypadku autonarracja jest najbardziej autentyczna i zarazem najmniej zniekształcona w procesie jej (re)konstrukcji.

Stosunkowo nową, choć już dobrze rozpoznaną w skali ogólnoświatowej strategią badawczą, gdzie dochodzi do (re)konstrukcji wiedzy o badanym terenie przez pryzmat tego, co osobiste, jest autoetnografia. W autoetnografii badacz posługuje się autonarracją, w ramach której analizuje własne przeżycia i poddaje refleksji osobiste doświadczenia życiowe, „odnosząc je do kontekstu społecznego, w jakim się pojawiły” (Kacperczyk 2014: 37). Autoetnografia przyjmuje różne postaci. Dla przykładu, odmiana autobiografii terenowej obecna jest m.in. w pracach Marcina Kafara (por. tegoż np. 2013, 2004). Autor artykułu pt. Od spotkania do wspólnoty. Autobiograficzny raport $z$ terenu relacjonuje w nim pobyt w łódzkim domu pomocy społecznej, przybliżając Czytelnikowi proces towarzyszenia przebywającym w nim pensjonariuszom. Obrazowane tu doświadczenie terenowe przyjmuje formę nie tylko refleksji antropologicznej, ale przede wszystkim autobiograficznej, ponieważ autor oddaje osobiste przeżycia związane z doświadczaniem spotkania z drugą osobą, a także sięga po utrwalone w pamięci wspomnienia z okresu dzieciństwa; jak się okazuje, dopiero takie podwojone mediowanie między „wczoraj” a „dziś” 
pozwala mu zrozumieć specyfikę zdarzeń, które stały się udziałem zarówno jego, jak i mieszkańców DPS-u (Kafar 2004).

Jak przekonuje Andrzej P. Wejland (2013), rys autobiograficzny stanowi kwintesencję także innej pracy Kafara, a mianowicie książki pt. W świecie wygnańców, wdów i sierot. O pewnym wariancie antropologii zaangażowanej (2013), będącej sprawozdaniem $\mathrm{z}$ wieloletniego pobytu $\mathrm{w}$ domu dla osób przewlekle chorych. Losy osobiste autora splatają się tu z losami ludzi, którzy znaleźli się na dalekim marginesie życia, stanowiąc pretekst do snucia opowieści rozpiętej między zaangażowaniem w życie Drugiego a życie własne (Kafar 2013).

Relacja autobiograficzna o proweniencji autoetnograficznej stanowi też istotne źródło wiedzy w badaniach nad społecznym światem wspinaczki w wydaniu Anny Kacperczyk. Autorka dowartościowuje w nich wiedzę płynącą z osobistego i etnograficznego doświadczania badanego terenu, m.in. poprzez uczestnictwo w kursie wspinaczkowym. Co więcej, dostrzega ona także rolę upodmiotowionego ciała badacza w prowadzonym przez niego procesie badawczym (Kacperczyk 2012, 2016).

Za znakomitą egzemplifikację pokrewnego podejścia w obszarze socjologicznych badań nad macierzyństwem posłużyć może studium Ewy Zakrzewskiej-Manterys przedstawiającej swoje doświadczenia związane $\mathrm{z}$ urodzeniem dziecka z zespołem Downa i - szerzej - kontekst społeczny bycia matką (Zakrzewska-Manterys 1995).

Ujęcie andragogiczne prezentuje Małgorzata Puć, która celem zrealizowanych przez siebie badań autobiograficznych uczyniła odkrycie subiektywnych znaczeń, jakie nadawała doświadczeniu ciąży o trudnym przebiegu. Autorka uwypukliła zamysł tej naukowej autoanalizy, skierowanej na „rozpoznanie potencjału rozwojowego tego doświadczenia, dotarcie do zmian w myśleniu, odczuwaniu, jakie były jego wynikiem" (Puć 2013: 64-65). W swoim tekście Puć dokonuje analizy autonarracji i fotonarracji, za pomocą których udokumentowała fragmenty swoich własnych doświadczeń.

Wydaje się, iż w dwóch ostatnich przykładach to życiowe epifanie ich autorek stanowiły najważniejszy powód namysłu nad własnymi doświadczeniami życiowymi i jednocześnie uczyniły z nich przedmiot naukowej autoanalizy. Niemniej jednak zdarza się, iż owe doświadczenia są dzielone z innymi lub zapośredniczone od innych osób. Być może tym wspólnym obszarem jest treść i jakość przeżywanej epifanii, czyli krytycznego wydarzenia życiowego. Zatem uznając pewną styczność, sprzężenie pomiędzy doświadczeniem życiowym badacza a biografiami badanych oraz decydując się na wysiłek ich poznania i zrozumienia, możemy odwołać się do podejścia auto/biograficznego (por. Pryszmont-Ciesielska 2009). Zastosowany w słowie ukośnik podkreśla tę podwójną relację, ponieważ z jednej strony pojawia się autobiografia badacza, z drugiej biografie badanych. Tak ukierunkowaną możliwość prowadzenia badań dostrzega m.in. Nod Miller. Uczestnicząc w badaniach nad oświatą dorosłych i całożyciowym uczeniem się, które polegały na tworzeniu 
i analizie narracji biograficznych, Miller włączyła do nich równolegle własne doświadczenia życiowe (Miller 2003). Kluczowe staje się więc tutaj „ja auto/biograficzne" - nierozłącznie wpisane w tożsamość badacza i w związku z tym uznane za specyficzne, kontekstualne i sytuacyjne (Stanley 1993, za: Miller 2003: 122). Zdaniem Miller, elementy tożsamości i pozycji społecznej badacza wpływają na przedmiot badań oraz sposób przedstawiania relacji z badań (tamże). Interesującym przykładem badań wykorzystujących to podejście jest studium Luby Jakubowskiej-Malickiej. Celem realizowanych przez autorkę badań była „charakterystyka tożsamości kulturowej «człowieka pogranicza» w kontekście tendencji globalizacyjnych" (Jakubowska 2011: 115). W przyjętym modelu badań uwzględniła swoje osobiste doświadczenia życiowe, przyjmując perspektywę narracyjno-auto/biograficzną. Oto, w jaki sposób uzasadniła tę decyzję:

Środowisko Polaków z Kazachstanu w szerszym rozumieniu jest mi bliskie, ponieważ sama reprezentuję tę kategorię. Dlatego też moim celem było zaaranżowanie przebiegu procesu badawczego w ten sposób, aby osobiste powiązania ze środowiskiem badanym nie tylko nie zakłóciły tego procesu, lecz odwrotnie - wzbogaciły go (tamże: 116).

W realizowanym projekcie badawczym autorka posłużyła się wywiadem biograficzno-narracyjnym. Wiedzę uzyskaną za pomocą wywiadów badaczka uzupełniła refleksją płynącą z osobistych życiowych doświadczeń. W rezultacie, tego rodzaju praktyka pozwoliła jej na rozpoznanie i zrozumienie interesującego ją zjawiska z dwóch perspektyw: biografii osób badanych i biografii własnej.

W celu precyzacji rozważań dotyczących rozumienia omówionych podejść badawczych z wykorzystaniem biografii ich istota została zilustrowana na rys 1 .

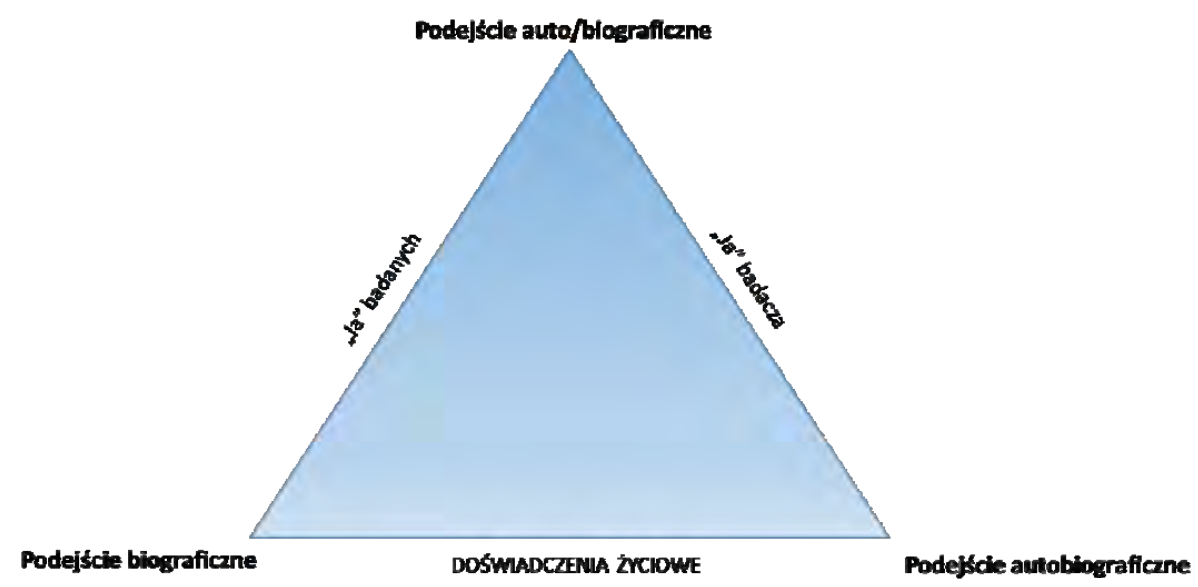

Rys. 1. Podejścia badawcze z wykorzystaniem biografii Źródło: opracowanie własne. 
Powyższy rysunek ukazuje możliwe podejścia do badań z wykorzystaniem biografii. Został on opisany na planie trójkąta, którego podstawę tworzą doświadczenia życiowe wspólne dla wszystkich umieszczonych na trzech wierzchołkach podejść, tj. biograficznego, autobiograficznego i auto/biograficznego. Przy czym doświadczenie życiowe stanowi jednocześnie przedmiot badań realizowanych przy pomocy trzech wyróżnionych podejść. Na jednym kontinuum znajduje się podejście biograficzne i autobiograficzne, które mają najbardziej względem siebie odmienny charakter. Integracja tych dwóch perspektyw daje nam trzecią jakość podejście auto/biograficzne. Jest ono zarazem pewnym kompromisem między dwoma pozostałymi podejściami do uprawiania badań biograficznych. W naszym przekonaniu, tego rodzaju propozycja pozwala badaczom na precyzyjne uchwycenie specyfiki realizowanych przez nich projektów badawczych, co pozwala na dookreślenie rodzaju uzyskanej przez badacza wiedzy naukowej. Przykładem projektu, który integruje trzy wyróżnione podejścia, są cykliczne spotkania badaczy pt. Biografia i badanie biografii, które z inicjatywy Elżbiety Kowalskiej-Dubas od 2008 r. organizowane są przez Zakład Andragogiki i Gerontologii Społecznej Uniwersytetu Łódzkiego (Dubas, Świtalski 2011; Dubas, Świtalski 2011a; Dubas, Stelmaszczyk 2014; Dubas, Stelmaszczyk 2015). Równie ciekawą i prezentującą wielorakie ujęcia badań z wykorzystaniem biografii jest dwujęzyczna seria wydawnicza „Perspektywy Biograficzne/Biographical Perspectives”, której pomysłodawcą jest Marcin Kafar z Katedry Badań Edukacyjnych Uniwersytetu Łódzkiego (Kafar 2011; Kafar, Modrzejewska-Świgulska 2013; Kafar 2016).

We wszystkich omawianych podejściach wypowiedzi (narracje autobiograficzne) postrzegane są więc zgodnie z ujęciem subiektywnym. Są one rozumiane jako „opowieści”, unikalne i niepowtarzalne interpretacje życia jednostek. Czas przyszły w relacji z przeszłością i teraźniejszością jest swoistego rodzaju zbiorem możliwości, rozwiązań i wskazówek, które jednostka może wykorzystać w celu urozmaicenia własnego rozwoju (Demetrio 2000: 75).

Uwzględniając powyższe rozwiązania, można dostrzec procesualny charakter zaproponowanych podejść - odnoszą się one do tworzenia narracji, opowiadania, procesu interpretacji życiowych doświadczeń, „życie poddane nie tylko refleksji własnej podmiotu, lecz również refleksji obserwatora - drugiego człowieka, badacza" (Lalak 2010: 21). W takiej perspektywie realizacja badań z wykorzystaniem biografii, w każdym z wymienionych podejść, jest refleksją badacza nad doświadczeniem: drugiego człowieka (w badaniach biograficznych), własnym (w badaniach autobiograficznych), osoby badanej i badacza (w badaniach auto/biograficznych). 


\section{Podejście auto/biograficzne w praktyce badawczej na przykładzie projektu pt. Nieformalne obszary uczenia się kobiet doświadczających macierzyństwa w perspektywie badań inspirowanych sztuka}

Zasadnym, z punktu widzenia dookreślania biograficznej perspektywy badawczej, jest także namysł nad istotą procesu badawczego z perspektywy „bycia badaczem”. Wątek ten zostanie przez nas zasygnalizowany w nawiązaniu do doświadczeń płynących z projektu pt. Portrety uczących się matek ${ }^{1}$. Szczegółowa analiza wskazanej kwestii wymaga jednak odrębnego opracowania. Tym samym, w celu dostrzeżenia istoty namysłu nad specyfiką procesu badawczego i roli badacza w badaniach biograficznych dla całości postępowania badawczego, w niniejszym artykule zostanie ona jedynie zasygnalizowana.

Wskazany projekt był dla autorek niniejszego artykułu wspólną przestrzenią zarówno podejmowanych czynności badawczych, jak i uczenia się w trakcie różnego rodzaju działań zespołowych. Główne problemy badawcze skoncentrowane były na następujących pytaniach: „Jakie doświadczenia macierzyństwa posiadają badane kobiety?", „Jakie trajektorie macierzyństwa przedstawiają narratorki?”, „Jakie są nieformalne obszary uczenia się kobiet doświadczających macierzyństwa?”, „W jaki sposób uczą się kobiety doświadczające macierzyństwa?”, „Jakie kompetencje nabywają kobiety doświadczające macierzyństwa?”, „Jaki potencjał posiada doświadczenie macierzyństwa dla narratorek?"

Osobami badanymi były matki z różnych środowisk społecznych (m.in. nastoletnie, niepełnosprawne, lesbijki, przewlekle chore). Badania zrealizowane zostały za pomocą triangulacji metodologicznej przez sześć badaczek. Główne inspiracje paradygmatyczne pochodziły z konstruktywizmu oraz teorii krytycznej. Przyjęta w pracy problematyka oraz procedura badawcza miały na celu ukazanie mikroświatów badanych matek w perspektywie ich indywidualnych doświadczeń, ujętych zgodnie ze spostrzeganą przez nie rzeczywistością. Ponadto, celem zrealizowanego projektu było uwrażliwienie odbiorców projektu na obecność matek w przestrzeni społecznej. Dowartościowanie autonomii w doświadczaniu macierzyństwa, a także uznanie potencjału nieformalnego uczenia się kobiet wyznaczały najważniejsze priorytety $\mathrm{w}$ podejmowanych działaniach badawczych. $\mathrm{Z}$ tego powodu zdecydowałyśmy się odwołać do badań jakościowych, które ujmują jednostki i przynależne im zjawiska społeczne z zachowaniem ich naturalności, kontekstualności i otwartości na różnorodność poznawania społecznych światów.

W naszym projekcie odwołałyśmy się do podejścia auto/biograficznego, ponieważ zainteresowało nas uczenie się kobiet w sytuacji macierzyństwa odczytane

\footnotetext{
1 Wskazany tytuł jest nazwą skróconą projektu badawczego pt. Nieformalne obszary uczenia się kobiet doświadczających macierzyństwa $w$ perspektywie badań inspirowanych sztukq. Jest on realizowany w ramach grantu wewnętrznego w Instytucie Pedagogiki Uniwersytetu Wrocławskiego.
} 
z historii ich życia. Przy czym materiał badawczy (narracje autobiograficzne) pochodził zarówno od badanych kobiet (indywidualne doświadczenia osób badanych), jak i osobistych doświadczeń badaczek (dotyczących: „bycia kobietą”, „bycia kobietą-matką", zainteresowana podejmowaną problematyką). W związku z tym, były to autobiografie badaczek oraz biografie badanych matek. Dopełnieniem tego podejścia było odwołanie się do wizualnych źródeł wiedzy o interesujących problemach, a mianowicie fotografii badanych kobiet. W tym celu posłużyłyśmy się strategiami badawczymi z użyciem fotografii (por. Konecki 2005), tj. samodzielnie fotografowałyśmy nasze badane oraz analizowałyśmy udostępnione przez nie prywatne fotografie.

Historie badanych kobiet gromadzone były także dzięki różnego rodzaju wywiadom badawczym, m.in. biograficzno-narracyjnym i pogłębionym. Ważną techniką była także analiza dokumentów z uwzględnieniem jakościowej analizy treści. Całość procesu uzupełniała refleksja badaczek skoncentrowana na ocenie podejmowanych czynności i działań poznawczych, a także spostrzeżenia na temat własnego rozwoju w trakcie realizowanych badań.

\section{Role badacza w biograficznych praktykach badawczych $\mathrm{z}$ perspektywy procesu uczenia się}

Analiza powyższych praktyk badawczych, a także doświadczenia płynące z realizowanego przez nas projektu były kontynuacją towarzyszącej nam od dłuższego czasu refleksji dotyczącej osoby badacza (jego roli, możliwości i ograniczeń) oraz świadomego, refleksyjnego doświadczania sytuacji badawczej przez badacza (badaczy). Kwestie te mają bowiem szczególne znaczenie w sytuacji pracy z biografią (zarówno własną, jak i osób zaproszonych do badań). W takim ujęciu bowiem, perspektywa „bycia” badaczem, funkcja poznawcza badań społecznych (badań jakościowych) poszerza się: od (roz)poznawania świata społecznego do (roz)poznawania samego siebie. W rezultacie realizacja badań staje się dla badacza nie tylko zadaniem zawodowym, ale również indywidualnym wyzwaniem edukacyjnym. Prowadzeniu badań towarzyszy zmiana - w zakresie myślenia, zachowania, postaw społecznych, wartości.

Tego rodzaju spostrzeżenie odnosi się bezpośrednio do dominującej w podejściu biograficznym (a tak naprawdę jedynej możliwej) podmiotowej relacji badawczej. Polega ona „przede wszystkim na specyficznym stosunku badacza do samego siebie jako jednostki ludzkiej, jego stosunku do partnera interakcji badawczej (badanego) oraz jego stosunku do rozpoznawanego problemu badawczego, czyli przedmiotu badań" (zob. Wyka 1993: 5, 44). W rezultacie, badacz i osoby badane bezpośrednio doświadczają wspólnie podzielanej przez siebie rzeczywistości społecznej (tamże: 55). Kluczową wartością jest również „refleksyjność”, którą 
można rozumieć nie tylko jako kompetencję konieczną do dostrzegania i nadawania znaczeń i sensów badanym doświadczeniom, ale także jako:

proces krytycznego namysłu nad Ja badacza (...). Jest to świadome doświadczanie siebie zarówno jako badacza, jak i respondenta, jako nauczyciela i ucznia, jako kogoś poznającego siebie wewnątrz procesu samego badania (Guba, Lincoln 2009: 306).

Tym niemniej, doświadczanie sytuacji badawczej przez badacza może przebiegać na różnych poziomach. W podejściu biograficznym podstawowym zadaniem badacza jest gromadzenie doświadczeń wpisanych $\mathrm{w}$ biografię zaproszonych do badań osób. Stąd też rola badacza jest determinowana potrzebą zgromadzenia materiału badawczego, który umożliwiałby (roz)poznawanie i (z)rozumienie rzeczywistości społecznej przez pryzmat świata przeżyć osób badanych. W takiej perspektywie niezwykle ważnymi, nadrzędnymi (z punktu widzenia procesu gromadzenia materiału badawczego) kompetencjami badawczymi są: zdolność nawiązywania relacji, aktywnego słuchania, uważność, umiejętność tworzenia atmosfery zapewniającej osobom badanym intymność, poczucie bezpieczeństwa, zdolność empatii. Z kolei w podejściu autobiograficznym dowartościowane zostaje indywidualne doświadczenie badacza czy też wiedza badacza płynąca z osobistego doświadczenia. Historia życia badacza staje się perspektywą, z której przygląda się on interesującym go zjawiskom w ich szerszym kontekście społeczno-kulturowym. W jego autobiograficznej narracji odbijają się przecinające się mikroświaty ludzi. W takiej perspektywie zatem szczególnego znaczenia nabierają: zdolność refleksji nad własnym doświadczeniem, samoobserwacja, zdolność jednostki do budowania samowiedzy, gotowość do krytycznego spojrzenia na własne doświadczenie. Natomiast w podejściu auto/biograficznym wskazane role badacza zostają ze sobą scalone. Zgromadzana przez badacza wiedza odnosi się zarówno do biografii własnej, jak i biografii Innego.

Badanie biografii może zatem inspirować badacza do świadomego doświadczania sytuacji badawczej, do analizy własnych reakcji podczas realizacji badań, do świadomego włączania własnego doświadczenia w proces badawczy (ze świadomością konsekwencji, jakie mogą z tego wynikać dla realizowanych badań i ich wyników). Tego rodzaju praktyki, tak jak zostało wspomniane, pozwalają na dookreślenie procesu badawczego jako specyficznego procesu uczenia się badacza (zarówno w wymiarze jego indywidualnego rozwoju, jak i rozwoju zawodowego).

Tego rodzaju potencjał badań dostrzegał już Stanisław Ossowski, który podkreślał, iż twórczość naukowa:

wzbogaca bardzo poważnie naszą wiedzę o ludzkim świecie, ukazuje nowe aspekty rzeczywistości, mnoży jej „wymiary”, uświadamia niedostrzegane związki, stawia nowe problemy społeczne i psychologiczne (...). 
Może powodować zmiany w stosunku do ludzi, skłaniać do rewizji dotychczas uznawanych skal wartości, pogłębiać rozumienie pewnych zjawisk społecznych i typów osobowych, może czynić człowieka mądrzejszym (Ossowski 2001: 183-184).

W sytuacji realizacji badań z wykorzystaniem biografii trudno nie zgodzić się z poglądami Ossowskiego, jednocześnie warto odnieść powyższą myśl do wszystkich podmiotów biorących udział w badaniu: osób badanych, badaczy, odbiorców. Nawiązując do własnego doświadczenia, a także przyglądając się praktykom badawczym w obszarze andragogiki, warto zwrócić uwagę na specyficzną rolę badacza-andragoga, którego charakteryzuje swoistego rodzaju zbliżenie roli człowieka dorosłego i roli badacza (badacz-człowiek dorosły, na różnych etapach dorosłości). Dorosłość badacza łączy się zatem z dorosłością osób badanych. W takiej perspektywie sytuację badawczą można postrzegać przez pryzmat przenikania się mikroświatów osób dorosłych (mikroświatów badacza i osób badanych) - „bycia” w relacji dorosłości (na różnych poziomach jej doświadczania). Zgodnie $\mathrm{z}$ takim rozumieniem, uwagę badaczy skupia z jednej strony „uczenie się biograficzne ludzi dorosłych, rola doświadczenia życiowego w poznawaniu, procesy nabywania i zmiany indywidualnej tożsamości” (Malewski 2010: 19), z drugiej strony (roz)poznawanie własnej biografii i nadawanie znaczenia własnym doświadczeniom (także tym, które wiążą się z „byciem badaczem”). Niemniej jednak, z punktu widzenia uskutecznianych badań oraz interpretacji materiału badawczego (ich czystości metodologicznej) badacz powinien być świadomy miejsca, jakie zajmuje jego własne doświadczenie w realizowanym przez niego projekcie.

W badaniach andragogicznych wykorzystujących biografię, w szczególności w badaniach autobiograficznych oraz auto/biograficznych, w których biografia badacza jest niejako „wplątana” w biografię osób badanych, relację badacz - badany charakteryzuje bliskość doświadczeń. Taka perspektywa jest dla badacza zarówno sytuacją inspirującą i twórczą, jak i trudną, uwikłaną w wiele dylematów związanych m.in. z zakorzenieniem badacza we własnej biografii, co wiąże się z indywidualnością jego myślenia, postrzegania i rozumienia². Jednakże dzięki świadomości owej specyfiki, badacz może w sposób intencjonalny, zgodny z zasadami realizacji badań naukowych i etyką badań społecznych kreować przestrzeń podejmowanych przez niego działań. W rezultacie staje się on aktywnym (wy)twórcą wiedzy o wybranych aspektach rzeczywistości (Pryszmont-Ciesielska 2008: 43); w sposób odpowiedzialny przyjmuje on podmiotową rolę badacza-andragoga.

W takim ujęciu proces badawczy można postrzegać przez pryzmat zarówno uczenia się z doświadczeń, jak i biograficznego uczenia się. W pierwszej sytuacji

\footnotetext{
2 „Filozoficzny warsztat badacza” współtworzą wybrane rodzaje (samo)wiedzy podmiotu poznającego: uwarunkowania intelektualne badacza (założenia ontologiczne, antropologiczne, epistemologiczne), uwarunkowania aksjologiczne badacza (świat wartości badacza, świat wartości badanych, etyka badań), uwarunkowania autobiograficzne badacza (Pryszmont-Ciesielska 2008: 45).
} 
chodzi o uczenie się bezpośrednio z doświadczeń wpisanych $\mathrm{w}$ realizację badań, w trakcie procesu badawczego. Jest to uczenie się „we współ/obecności, we współ/udziale i współ/działaniu: w zdarzeniach, w sytuacjach życiowych, poprzez styczności i interakcje w tym samym czasie i przestrzeni, poprzez spotkania, rozmowy, dialog, obserwacje, działanie. Jest uczeniem się w relacjach, w których powstają doświadczenia" (Dubas 2011: 7-8). W takiej sytuacji badacz poszerza samowiedzę dotyczącą jego samego, jak i wiedzę oraz doświadczenie badawcze (zawodowe). Z drugiej strony, włączenie przez badacza własnych doświadczeń biograficznych i traktowanie ich jako pełnoprawnego materiału badawczego jest źródłem biograficznego uczenia się badacza. Wykorzystuje on wówczas samoświadomość, dzięki czemu uczy się z własnej biografii „przez podsumowanie, refleksję, samorefleksję, opowiadanie historii innym i sobie samym” (Bron 2006: 19). W tym miejscu warto także podkreślić, iż w rzeczywistości proces biograficznego uczenia się może odnosić się do uczenia się z własnej biografii i uczenia się z biografii osób badanych (Dubas 2011a: 6-9).

Dyskusja dotycząca naukowego statusu podejścia, a właściwie podejść biograficznych, wskazując na różnorodność wykorzystania biografii w badaniach, pozwala zatem dostrzec subtelne różnice w zakresie (wy)korzystania w badaniach doświadczeń badacza. Patrząc szerzej, stwarza możliwość dostrzeżenia różnego rodzaju kontekstów realizacji badań. Z punktu widzenia bycia badaczem, postrzeganie procesu badawczego jako procesu uczenia się pozwala na uczynienie aktywności badawczej mniej oczywistej, co stwarza szansę na poszerzenie lub wręcz otwarcie refleksji na temat różnych form doświadczania sytuacji badawczej.

\section{Refleksja zamykająca}

Realizacja badań z wykorzystaniem biografii wciąż wyznacza nowe kierunki myślenia o procesie badawczym. W dużej mierze dookreślanie biograficznej perspektywy badawczej - zarówno na poziomie rozstrzygnięć teoretycznych, jak i metodologicznych - łączy się z nieustannym zadawaniem pytań dotyczących istoty i rozumienia samego terminu „biografia” i poszukiwaniem na nie odpowiedzi. Śledząc różnego rodzaju praktyki badawcze, można dostrzec, iż (być może paradoksalnie) zarówno problem jednoznacznego uchwycenia natury biografii, jak i precyzyjnego dookreślenia badań biograficznych łączy badaczy reprezentujących różne nauki. Tym samym dyskusja dotycząca biografii i badania biografii ma charakter interdyscyplinarny. Na ile one są zbieżne, a na ile specyficzne? To pytanie nieustannie inspiruje badaczy do refleksji.

Wyróżnione powyżej podejścia badawcze wpisane w biograficzną perspektywę badawczą stanowią jedną z wielu propozycji myślenia o badaniach realizowanych w nurcie biograficznym. Jest to jednak spójna koncepcja porządkująca kwestię rozróżniania badań biograficznych, autobiograficznych, auto/biograficznych. 
Zaprezentowane $\mathrm{w}$ tekście projekty badań pozwalają na uchwycenie różnych źródeł wiedzy w procesie (roz)poznawania świata społecznego, którymi mogą być: doświadczenia osób badanych (podejście biograficzne), badacza (podejście autobiograficzne), osób badanych i badacza (podejście auto/biograficzne).

Pod względem strukturalnym wskazane stanowisko pozwala na zmniejszenie dystansu między postrzeganiem biografii i autobiografii a rozumieniem procesu badawczego $\mathrm{z}$ wykorzystaniem biografii. Takie ujęcie może być interesującym rozwiązaniem w procesie (roz)poznawania natury badań biograficznych, nie tylko w obszarze refleksji andragogicznej.

To, na co jednak warto zwrócić uwagę, to konieczność realizacji badań w sposób refleksyjny i świadomy. Jedną z możliwości, która pozwala badaczom na tego rodzaju praktyki, jest postrzeganie procesu badawczego przez pryzmat procesu uczenia się badacza. Samoobserwacja, świadomość własnych uwarunkowań i doświadczeń oraz analiza poszczególnych etapów i czynności badawczych bez wątpienia pozwalają badaczom na coraz bardziej precyzyjne postępowanie, co niewątpliwie znajduje swoje odzwierciedlenia w realizacji rzetelnych i prawomocnych badań naukowych. W rezultacie refleksyjny badacz to osoba, która uczy się przede wszystkim dzięki analizie własnego postępowania i krytycznemu spojrzeniu na własny warsztat pracy, w który niejednokrotnie wpisana jest jego biografia.

\section{Bibliografia}

Alheit P. (2011) Podejście biograficzne do całożyciowego uczenia się, „Teraźniejszość Człowiek - Edukacja", nr 3 (55), s. 7-21.

Bron A. (2006) Rozumienie uczenia się w teoriach andragogicznych, „Teraźniejszość Człowiek - Edukacja”, nr 4 (36), s. 7-24.

Bron A. (2009) Biograficzność w badaniach andragogicznych, „Dyskursy Młodych Andragogów", nr 10, s. 37-54.

Demetrio D. (2000) Autobiografia. Terapeutyczny wymiar pisania o sobie, Kraków, Oficyna Wydawnicza „Impuls”.

Denzin N. K., Lincoln Y. S. (2009) Wprowadzenie. Dziedzina i praktyka badań jakościowych w: Metody badań jakościowych, N. K. Denzin, Y. S. Lincoln (red.), t. 1, Warszawa, Wydawnictwo Naukowe PWN, s. 19-62.

Dubas E. (2011) Uczenie się w (własnej) biografii - wprowadzenie w: Uczenie się $z$ (własnej) biografii, E. Dubas, W. Świtalski (red.), t. 1, Łódź, Wydawnictwo Uniwersytetu Łódzkiego, s. 5-11. 
Dubas E. (2011a) Uczenie się z biografii Innych - wprowadzenie w: Uczenie się z biografii Innych, E. Dubas, W. Świtalski (red.), t. 2, Łódź, Wydawnictwo Uniwersytetu Łódzkiego, s. 5-9.

Dubas E., Świtalski W. (red.) (2011) Uczenie się z (własnej) biografii, Łódź, Wydawnictwo Uniwersytetu Łódzkiego.

Dubas E., Świtalski W. (red.) (2011a) Uczenie się z biografii Innych, Łódź, Wydawnictwo Uniwersytetu Łódzkiego.

Dubas E., Stelmaszczyk J. (red.) (2014) Biografie edukacyjne. Wybrane konteksty, Łódź, Wydawnictwo Uniwersytetu Łódzkiego.

Dubas E., Stelmaszczyk J. (red.) (2015) Biografie i uczenie się, Łódź, Wydawnictwo Uniwersytetu Łódzkiego.

Giza-Poleszczuk A. (1990), Autobiografia między symbolem a rzeczywistościq, „Kultura i Społeczeństwo", nr 1, s. 95-109.

Golonka-Legut J. (2013) Potencjał edukacyjny doświadczenia życiowego osób starszych z perspektywy czasu, dysertacja doktorska, Uniwersytet Wrocławski, materiał niepublikowany.

Golonka-Legut J. (2015) Uczenie się w perspektywie biograficzności. Perspektywa andragogiczna, „Rocznik Andragogiczny”, s. 101-118.

Guba E. G., Lincoln Y. S. (2009) Kontrowersje wokół paradygmatów, sprzeczności i wyłaniające się zbieżności w: Metody badań terenowych, N. K. Denzin, Y. S. Lincoln (red.), t. 1, Wydawnictwo Naukowe PWN, s. 281-312.

Helling I. K. (1990) Metoda biograficzna w socjologii, Warszawa-Poznań, PWN.

Jakubowska L. (2011) Tożsamość kulturowa Polaków z Kazachstanu w kontekście tendencji globalizacyjnych, Legnica, Wydawnictwo Państwowej Wyższej Szkoły Zawodowej im. Witelona w Legnicy.

Jurgiel-Aleksander A. (2013) Doświadczenie edukacyjne w perspektywie andragogicznej. Studium biograficzno-fenomenograficzne, Gdańsk, Wydawnictwo Uniwersytetu Gdańskiego.

Kacperczyk A. (2012) Badacz i jego ciało w procesie zbierania i analizowania danych na przykładzie badań nad społecznym światem wspinaczki, „Przegląd Socjologii Jakościowej", 31 lipca, t. 8, nr 2, s. 32-63.

Kacperczyk A. (2014) Autoetnografia - technika, metoda, nowy paradygmat? O metodologicznym statusie autoetnografii, „Przegląd Socjologii Jakościowej”, 31 sierpień, t. 10 , nr 3, s. 32-74. 
Kacperczyk A. (2016) Społeczne światy. Teoria - empiria - metody badań. Na przykładzie społecznego świata wspinaczki, Łódź, Wydawnictwo UŁ.

Kafar M. (2004) Od spotkania do wspólnoty. Autobiograficzny raport z terenu w: Codzienne i niecodzienne. O wspólnotowości w realiach dzisiejszej Łodzi, G. E. Karpińska (red.), Łódź, s. 79-101.

Kafar M. (2011) Biograficzne epifanie w kontekście tworzenia podstaw jakościowego kolektywu myślowego w: Biografie naukowe. Perspektywa transdyscyplinarna, M. Kafar (red.), Łódź, Wydawnictwo Uniwersytetu Łódzkiego, s. 2-66.

Kafar M. (red.) (2011) Biografie naukowe. Perspektywa transdyscyplinarna, Łódź, Wydawnictwo Uniwersytetu Łódzkiego.

Kafar M. (2013) W świecie wygnańców, wdów i sierot. O pewnym wariancie antropologii zaangażowanej, Łódź, Wydawnictwo Uniwersytetu Łódzkiego.

Kafar M. (red.) (2016) Auto/biograficzne aspekty praktyk poznawczych, Łódź, Wydawnictwo Uniwersytetu Łódzkiego.

Kafar M., Modrzejewska-Świgulska M. (red.) (2013) Autobiography, biography, narration: research practice for biographical perspectives, Łódź, Wydawnictwo Uniwersytetu Łódzkiego.

Konecki K. (2005) Wizualne wyobrażenia. Główne strategie badawcze w socjologii wizualnej a metodologia teorii ugruntowanej, „Przegląd Socjologii Jakościowej”, grudzień, t. 1, nr 1, s. 42-63.

Kvale S. (2004) InterViews. Wprowadzenie do jakościowego wywiadu badawczego, Białystok, Wydawnictwo „Trans Humana”.

Lalak D. (2010) Życie jako biografia. Podejście biograficzne w perspektywie pedagogicznej, Warszawa, Wydawnictwo Akademickie Żak.

Malewski M. (1998) Teorie andragogiczne. Metodologia teoretyczności dyscypliny naukowej, Wrocław, Wydawnictwo Uniwersytetu Wrocławskiego.

Malewski M. (2010) Od nauczania do uczenia się. O paradygmatycznej zmianie $w$ andragogice, Wrocław, Wydawnictwo Naukowe Dolnośląskiej Szkoły Wyższej.

Mazurek E. (2013) Biografie edukacyjne kobiet dotkniętych rakiem piersi, Wrocław, Oficyna Wydawnicza Politechniki Wrocławskiej.

Miller N. (2003) Auto/biografia w badaniach nad edukacja i uczeniem się całożyciowym, „Teraźniejszość - Człowiek - Edukacja”, nr 1(1), s. 121-140. 
Ossowski S. (2001) O osobliwościach nauk społecznych, Warszawa, Wydawnictwo Naukowe PWN.

Pryszmont-Ciesielska M. (2008) Badacz wobec kultury - o „podróżowaniu”, czyli o badaniu świata społecznego w: Kultura i edukacja (konteksty i kontrowersje), W. Jakubowski (red.), Kraków, Oficyna Wydawnicza „Impuls”, s. 41-53.

Pryszmont-Ciesielska M. (2009) Podejście auto/biograficzne $w$ badaniach nad edukacja - propozycja metodologiczna, „Teraźniejszość - Człowiek - Edukacja”, nr 2 (46), s. 37-49.

Puć M. (2013) Trudne pięknego początki. Ciq̨ża wysokiego ryzyka - rozwojowy etap macierzyństwa $w$ perspektywie auto/biograficznej w: Macierzyństwo $w$ relacjach auto/biograficznych i fotografiach kobiet, M. Pryszmont-Ciesielska (red.), Wrocław, Oficyna Wydawnicza Atut, s. 59-80.

Skibińska E. (2006) Mikroświaty kobiet. Relacje autobiograficzne, Warszawa, Wydawnictwo Instytutu Technologii i Eksploatacji - PIB.

Stanley L. (1993) On auto/biography in socjology, „Socjology”, vol. 27, no 1.

Stanley L. (2008) Madness to the method? Using a narrtive methodology to analyse large - scale complex social phenomena, „Qualitative Research”, no 8.

Thomas W. I., Znaniecki F. (1976) Chłop polski w Europie i Ameryce: Organizacja grupy pierwotnej, Warszawa, Ludowa Spółdzielnia Wydawnicza.

Urbaniak-Zając D. (2011) Biograficzna perspektywa badawcza w: Uczenie się z (własnej) biografii, E. Dubas, W. Świtalski (red.), Łódź, Wydawnictwo Uniwersytetu Łódzkiego, s. 11-27.

Usher R. S. (1996) A critique of the Neglected Epistemological Assumptions of Educational Research w: Understanding Educational Research, D. Scott, R. S. Usher (red.), London-New York, Routledge.

Wejland A. P. (2013) Zaangażowanie i autobiografia w: M. Kafar, W świecie wygnańców, wdów i sierot. O pewnym wariancie antropologii zaangażowanej, Łódź, Wydawnictwo Uniwersytetu Łódzkiego, s. 9-17.

Wyka A. (1993) Badacz społeczny wobec doświadczenia, Warszawa, Instytut Filozofii i Socjologii PAN.

Zakrzewska-Manterys E. (1995) Down i zespół wątpliwości. Studium z socjologii cierpienia, Warszawa, Wydawnictwo Naukowe Semper. 